\title{
Reseñas
}

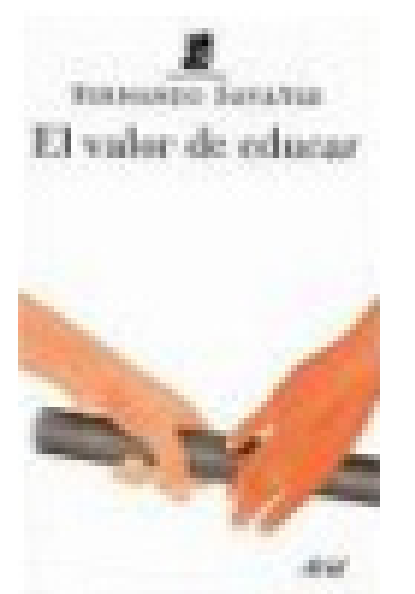

\section{El valor de educar}

Fernando Savater

Ariel, España, 2006

El valor de educar puede llegar a convertirse, sin duda alguna, en un libro de reflexión clásica sobre un tema tan apasionante como controversial.

A través de más de 200 Páginas, Fernando Savater, plantea en éste ensayo posibles respuestas a interrogantes de tipo filosóficas relativas a la educación, promueve la equidad de género (comienza con una carta dirigida a una maestra y finaliza con otra dirigida a una ministra), hace una defensa más que diplomática a la labor desempeñada por los docentes, elabora un recorrido desde el aprendizaje humano, contemplado desde una perspectiva antropológica, hasta llegar a realizar un extracto resumido de pensamientos más sobresalientes de personajes tan dispares como Dewey, Russel o Machado.

El lector puede verse de repente inmerso en una lectura reflexiva que aborda temas como el aprendizaje humano, los contenidos de la enseñanza, el eclipse de la familia, la disciplina de la libertad y otros aspectos por demás interesantes que invitan a hacer un alto para tratar de dar sentido a la actividad educativa y social.

Tal vez este libro pudiera resultar para muchos un tanto rebuscado y redundante, la principal crítica que puede presentarse es referente al estilo y la forma tan característica del filósofo, más no por ello deja de ser un libro exquisito especialmente en sus últimos dos capítulos en los que hace referencia a dos concepciones por demás originales: "Humanidad sin humanidades" y "Educar es universalizar".

El valor de educar no sólo debe ser leído por aquellos cuya labor es primordialmente educativa, sino por todos los actores que se reúnen en torno al fenómeno educativo, ya que este libro surge precisamente del interés de un sector sindical mexicano para que se difundan y se conozcan los valores que encierra la educación en la libertad y para la libertad. 